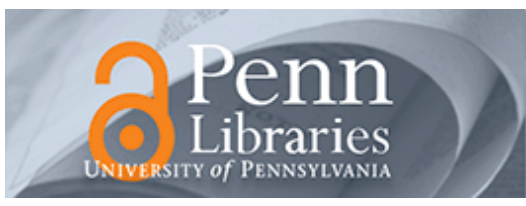

University of Pennsylvania
ScholarlyCommons

Departmental Papers (ASC)

Annenberg School for Communication

2017

\title{
The Political Uses and Abuses of Civility and Incivility
}

Kathleen Hall Jamieson

University of Pennsylvania, kjamieson@asc.upenn.edu

Allyson Volinsky

Ilana Weitz

Kate Kenski

Follow this and additional works at: https://repository.upenn.edu/asc_papers

Part of the Social Influence and Political Communication Commons

\section{Recommended Citation (OVERRIDE)}

Jamieson, K. H., Volinsky, A., Weitz, I., and Kenski, K. (2017). “The Political Uses and Abuses of Civility and Incivility” in K. H. Jamiesone and K. Kenski (eds.), The Oxford Handbook of Political Communication. New York, Oxford University Press. 


\title{
The Political Uses and Abuses of Civility and Incivility
}

\begin{abstract}
After exploring the challenges involved in defining incivility, this chapter addresses the evolution of the concept, notes the dispute over trend lines, and précises work on its psychological effects. It then outlines some functions that civility and incivility serve, such as the functions of differentiating and mobilizing, marginalizing the powerless, expressing, and deliberating. The use of calls for civility as a means of social control is discussed, and then the chapter flags questions worthy of additional attention.
\end{abstract}

\section{Keywords}

civility, incivility, effects of incivility, functions of civility, functions of incivility

\section{Disciplines}

Communication | Social and Behavioral Sciences | Social Influence and Political Communication 


\section{The Political Uses and Abuses of Civility and Incivility ว}

Kathleen Hall Jamieson, Allyson Volinsky, Ilana Weitz, and Kate Kenski

The Oxford Handbook of Political Communication

Edited by Kate Kenski and Kathleen Hall Jamieson

Print Publication Date: Aug 2017

Subject: Political Science, Political Theory, Comparative Politics

Online Publication Date: Jan 2015

DOI: 10.1093/oxfordhb/9780199793471.013.79_update_001

Additional citations.

Updated on 11 January 2018. The previous version of this content can be found here.

\section{Abstract and Keywords}

After exploring the challenges involved in defining incivility, this chapter addresses the evolution of the concept, notes the dispute over trend lines, and précises work on its psychological effects. It then outlines some functions that civility and incivility serve, such as the functions of differentiating and mobilizing, marginalizing the powerless, expressing, and deliberating. The use of calls for civility as a means of social control is discussed, and then the chapter flags questions worthy of additional attention.

Keywords: civility, incivility, effects of incivility, functions of civility, functions of incivility

Civility is a social norm and a standard "of behavior... based on widely shared beliefs [about] how individual group members ought to behave in a given situation" (Fehr and Fischbacher, 2004, 185). Put differently, "A norm of civility defines the kinds of behavior that persons can rightfully expect from others" (Sinopoli, 1995, 613). Like other injunctive norms, civility "specif[ies] what people approve and disapprove within the culture and motivate[s] action by promising social sanctions for normative or counternormative conduct" (Reno et al., 1993, 104).

After exploring the challenges involved in defining incivility, this chapter addresses the evolution of the concept, notes the dispute over trend lines, précises work on its psychological effects, outlines some functions served by civility and incivility, and flags questions worthy of additional attention. 


\section{The Challenges of Definition}

Scholars agree that providing a settled definition of civility is all but impossible because, as Benson notes, the "communicative, rhetorical practices" of civility and incivility "are always situational and contestable" $(2011,22)$. Put differently, "[c]ivility in discourse is a matter of socially secured agreements to conform to the local culture.... What is normal in public discussion in some places is rude in others; and (p. 206) what is considered a normal way of showing respect in some venues seems mannered and arid in others" (Ferree et al., 2002, 313-314). For that reason, among others, Sapiro observes, "It would take an advanced degree in alchemy, not political science, to draw a tidy but reasonably comprehensive definition out of the literature to which one must turn to learn about civility as it is understood today" (quoted in Herbst, 2010, 12).

What most definitions do share is the notion that civility connotes a discourse that does not silence or derogate alternative views but instead evinces respect. Often the object of respect is one's interlocutor or fellows. So for Carter, civility involves "an attitude of respect, even love, for our fellow citizens" (1998, xii); for Shils, "respect for the dignity and the desire for dignity of other persons" (1997, 338); for Hayek, a "method of collaboration" (1976, 3); for Andersson and Pearson, "low-intensity deviant behavior with ambiguous intent to harm the target, in violation of workplace norms of mutual respect" (1999, 457); and for Sobieraj and Berry, "political argumentation characterized by speakers who present themselves as reasonable and courteous, treating even those with whom they disagree as though they and their ideas are worthy of respect" $(2011,20)$. For Coe, Kenski, and Rains, incivility refers to "features of discussion that convey an unnecessarily disrespectful tone toward the discussion forum, its participants, or its topics" $(2014,660)$. However, for other scholars the object of respect or disrespect is broader. For example, Papacharissi $(2004,267)$ argues: "Civility is positive collective face; that is, deference to the social and democratic identity of an individual. Incivility can be defined as negative collective face; that is, disrespect for the collective traditions of democracy." As scholars have shifted to a constructionist perceptive, civility has been less likely to be defined in terms of use of specific words or practice and more likely to be cast as a mode of interaction and a perception. "Everyday incivility can be thought of as commonplace actions and interactions that are perceived to be rude or inconsiderate," write Phillips and Smith $(2003,85)$.

Much contemporary theorizing about civility is tied to presuppositions about the nature of deliberation and to discussions of the appropriate forms that disagreement on moral matters should take in a political system such as ours. Political philosophers derive their sense of the role of civility in the public sphere from their concept of deliberation and the public good. For example, Rawls's duty of civility not only entails a moral duty to explain how an advocated policy "can be supported by the political values of public reason," but also "involves a willingness to listen to others and a fairmindedness in deciding when accommodations to their views should reasonably be made" $(1996,217)$. 
From earlier times to more recent ones, rudeness and civility have been cast as antonyms. Accordingly, Chaucer notes of the carpenter in The Miller's Tale (n.d., 119): "He knew nat Catoun [a Latin handbook on appropriate behavior], for his wit was rude," and in The American Commonwealth Lord Bryce observes, "Yet neither are they rude for to get on in American politics one must be civil and pleasant" (1921, Part 1, 148).

\section{(p. 207) The Evolution of the Concept of Incivility}

Although lexically kin to the Roman's civis (citizen) and civitas (citizenship) (Simpson, 1960, 109), the word civility (civilitas) did not become fashionable (Gillingham, 2002, 281) until publication of Erasmus's sixteenth-century De Civilitate Morum Puerilium (Knox, 1995; Carter, 1998, 14). That work's ancestors include the twelfth-century Liber Urbani of Daniel of Beccles and the much older, third-century "commonplace secular morality" of the Distichs of Cato (Gillingham, 2002, 267). Widely circulated in the Middle Ages, the Distichs of Cato was published in the colonies by Benjamin Franklin.

In early modern England and Western Europe, "the terms 'civil' and 'civility' gradually displac[ed] 'courteous' and 'courtesy' as the fashionable terms denoting approved conduct" (Gillingham, 2002, 267), a transformation documented by Elias (2000), Becker (1988), and Bryson (1998), among others. In the process, "during the sixteenth century the term 'civility' began to take on some of the connotations of 'civilization' as the opposition between the 'civil' and the 'barbaric' implicit in classical writings was allegedly developed in response to the challenge presented by the discovery of the 'savage inhabitants of the New World, and then applied in a contrast between English civility and Irish barbarity" (Gillingham, 2002, 269).

\section{Incivility Trends}

Depending on how one defines the term, measures the phenomenon, and brackets the period of study, civility in general either is (Carter, 1998, xi) or is not on a downward slope (see Altschuler and Blumin, 2000). Similarly, comity in Congress either is (Uslaner, 1996) or is not on a downward path (Nickels, 1995; Jamieson and Falk, 2000). An alternative view is that congressional civility rises and falls with the changes driven by the interaction of individuals and events. The patterns revealed by a charting of both the requests to take down words in the House and of requests that led to a ruling indicates that 1946 and 1995 were high points of incivility and that "those who believe that incivility has been on an upward course since the Vietnam war are, by this measure, mistaken" (Jamieson and Falk, 2000, 108).

There is nonetheless general agreement that, whether or not twenty-four-hour-a-day cable talk, talk radio, and the Web have increased the amount of uncivil discourse, "the uncivil tendencies in American culture are more apparent and abundant thanks to pervasive media" (Herbst, 2010, 26). After examining ten weeks of data from political blogs, talk radio, and cable news analysis programs, Sobieraj and (p. 208) Berry found that outrage, a 
specific kind of incivility that involves trying to provoke a visceral response from an audience, "punctuates speech and writing across formats" $(2011,26)$, and "89.6 percent of cases included in the sample contained at least one outrage incident." Coe, Kenski, and Rains found that in the online discussions they analyzed from a newspaper website, "more than one out of every five comments were uncivil, and 55.5 percent of the article discussions contained at least some incivility" $(2014,673)$.

\section{Incivility's Psychological Effects}

There is general agreement that uncivil discourse is emotionally arousing (Mutz, 2007). Moreover, being the target of uncivil remarks (including insults and rude behavior in public) can elicit strong responses (cf. Vasquez et al., 2013); reduce effective cognitive processing, productivity, and creativity (Porath and Erez, 2007, 2009; Rafaeli et al., 2012, 931); and elicit reciprocal aggression (Andersson and Pearson, 1999).

The effects of viewing uncivil behavior are less settled. In a study focused on exchanges on a talk show, Mutz and Reeves concluded that "political trust is adversely affected by levels of incivility" in televised political exchanges arguing that "the format of much political television effectively promotes viewer interest, but at the expense of political trust" $(2005,1)$. Anderson and colleagues found that "uncivil blog comments can polarize... along the lines of religiosity and issue support" $(2014,274)$ in their study on risk perceptions of emerging technologies. A burgeoning body of work on the nature, causes, and impact of online incivility has emerged and with it efforts to minimize both the behavior and its harmful effects (Gervais, 2015; Santana, 2014; Stroud et al., 2015).

By contrast, Brooks and Geer find: "While uncivil messages in general-and uncivil traitbased messages in particular-are usually seen by the public as being less fair, less informative, and less important than both their civil negative and positive counterparts, they are no more likely to lead to detrimental effects among the public. In fact, incivility appears to have some modest positive consequences for the political engagement of the electorate" $(2007,1)$.

Other research has shown that when a news article was embedded in an uncivil blog post, the article's perceived credibility increased (Thorson, Vraga, and Ekdale, 2010). Borah (2013) found that incivility increased perceptions of credibility of a news article, but it also decreased political trust and efficacy. In a study of online comments, Coe, Kenski, and Rains (2014) found that uncivil commenters were slightly more likely to include statistics as evidence; uncivil comments were also more likely to receive more reactions from readers in the form of thumbs-down ratings. Depending on one's point of view, negative reactions to online posts could be considered harmful, but for others, the mere fact that people are responding at all could be considered beneficial to public discourse as a sign of increased participation. 


\section{(p. 209) The Functions of Incivility and Civility}

Because civility and incivility are "strategic assets used by those pursuing specific interests, whether humanitarian efforts or far less admirable ones" (Herbst, 2010, 124), we parse the remainder of this chapter into sections on the various functions served by civility and incivility. In the process of so doing, we outline the differentiating, mobilizing, expressive, and silencing functions of incivility; the social and deliberative functions of civility; and the ways in which calls for civility can be used to disempower.

\section{The Functions of Incivility}

\section{Incivility's Differentiating and Mobilizing Functions}

Insults and invective are a powerful means of differentiating an in-group from an outgroup, an opponent from an ally. Since members of a group tend to exaggerate their differences with out-groups (Robbins and Krueger, 2005)-believing out-group members to be rather homogeneous and in-group members less so (Linville and Fischer, 1993), holding members of out-groups to be less human than those in the in-group (Leyens et al., 2003), and perceiving out-group attitudes to be more extreme than they actually are (Gawronski, Bodenhausen, and Banse, 2005; Jamieson and Cappella, 2008)-the fact that forms of attack such as ad hominem are employed against out-group members should be unsurprising.

Precisely because it evokes a strong emotional response, incivility is also a strategic tool in the arsenal of individuals seeking dramatic social or political change. Those carrying the flag for strategic incivility argue, as Schudson does, that "democracy may require withdrawal from civility itself....We call the people who initiate such departures from civility [as social movements, strikes, demonstrations] driven, ambitious, unreasonable, selfserving, rude, hot-headed, self-absorbed-the likes of Newt Gingrich and Martin Luther King and William Lloyd Garrison" (1997, 308).

As the record of agitators such as Garrison confirms, invective can serve as an assertion of identity and power by those who are being marginalized by a majority community (Murray, 1983). It can also act as an expression of outrage against evils such as genocide or slavery, which exist on a scale and of a kind that rupture the assumptions of the social order (see Aminzade and McAdam, 2002; Gould, 2009).

"[O]ffering up an 'enemy'... as the source of the problem" is a way of harnessing anger, an "emotion political organizers need to capture and channel" (Ost 2004, 229). As a result, invective has been a primary weapon of those arguing that an opponent is a heretic, a miscreant, or worse; unsurprisingly, such assaults elicit the kind of reciprocation in kind (p. 210) revealed by the psychological studies cited earlier. So, for example, Martin Luther attacked the "'brainless and illiterate beast in papist form,'” Thomas More called Luther both "an apostate and a pimp" (Furey, 2005, 469), and Thomas Cooper (1792) used invec- 
tive against invective in his Reply to Mr. Burke's Invective Against Mr. Cooper, and Mr. Watt. $^{1}$

\section{Incivility as a Means of Marginalizing the Powerless}

Just as incivility can be a tool of insurrection, it can also be marshaled against those seeking power by those in control. Some argue that online flaming "is an expression of cyberspace machismo which is often practiced more often against women and women's online groups as a kind of sexual harassment" (Vrooman, 2002, 53), a finding consistent with evidence from 2008 attacks on the Web posts by women objecting to sexist portrayals of the candidacy and person of Democratic presidential aspirant Hillary Clinton (Jamieson and Dunn, 2008).

\section{Incivility's Expressive Function}

Whether incivility is to be lauded or lamented is answered differently by different theorists and variously in different times, places, and circumstances. Accordingly, in ancient Rome, what was appropriate in one venue was frowned upon in another. In that tradition, vituperatio, the speech of reproach, was as much a part of the curriculum as the speech of praise (laus) and as such treated in Cicero's De Inventione (2:28-31, 177-178) and in the Ad Herrennium (3:10-15). To disparage or blame, the rhetor attacked the target for lacking the positive attributes that are the focus of a speech of praise, for example achievements, desirable characteristics such as speed or health, and virtues. By Craig's count there were "seventeen conventional loci of invective established in Greek and Roman practice by Cicero's time" (2004, 4-5): embarrassing family origin; being unworthy of one's family; physical appearance; eccentricity of dress; gluttony and drunkenness, possibly leading to acts of crudelitas and libido; hypocrisy for appearing virtuous; avarice, possibly linked with prodigality; taking bribes; pretentiousness; sexual misconduct; hostility to family; cowardice in war; squandering of one's patrimony/financial embarrassment; aspiring to regnum or tyranny; cruelty to citizens and allies; plunder of private and public property; and oratorical ineptitude.

Exemplifying what many would define as invective, in his widely praised attack on Piso, Cicero called his adversary a monster, a butcher, a scoundrel, and a gelded pig (Arena, 2007, 152). What was rhetorically appropriate when condemning an enemy was less so when addressing friends. So, for example, in De Officiis (Book 1, 49-51), "What one can observe in human society as a whole is fundamental. The bond of that society is reason and speech; they reconcile men to each other and join them in a sort of natural community by teaching, by learning, by communicating, by discussing, by judging."

\section{The Function of Civility in Deliberation}

If the public sphere is to be inclusive, productive, and deliberative, it requires norms of interpersonal exchange. Unsurprisingly then, in his Manual of Parliamentary Practice, (p. 211) Thomas Jefferson observed, "It is very material that order, decency, and regularity be preserved in a dignified public body" (1868, 14). Adopted on April 7, 1789, the House of Representatives' rules of decorum specified, among other things, that a member "shall 
confine himself to the question under debate, avoiding personality" (Jefferson, 1868, 38). In short, a member should not arraign or impugn the motive of another member.

Spaces predicated on cooperative engagement commonly adopt similar rules. For example, Wikipedia proclaims: "Civility is part of Wikipedia's code of conduct and one of Wikipedia's five pillars. The civility policy is a standard of conduct that sets out how Wikipedia editors should interact. Stated simply, editors should always treat each other with consideration and respect.... Someone may very well be an idiot. But telling them so is neither going to increase their intelligence nor improve your ability to communicate with them" (Civility, n.d.).

Codes such as Jefferson's and Wikipedia's are consistent with political theorists' notion, expressed by Gutmann and Thompson, that mutual respect "lies at the core of reciprocity and deliberation in a democracy" (1996, 79; see also Darwall, 1977). Democracies cannot, in Lynch's (2011) phrase, be "spaces of reasons" unless we are able "to find common currency with those with whom we must discuss practical matters." Because "civility... is really the very glue that keeps an organized society from flying apart" (Burger, 1975), "it makes practical sense to embrace civility as a norm... in the rhetorical exchanges that occur between those in an ongoing relationship, and... those who have come together as a community to address problems" (Jamieson, 2000, 4-5). For some, this means that deliberative civility focuses not on "what is communicated, whether these be reasons, arguments, propositions, or whatever..., [but rather on] how I address you and how I interpret and respond to your claims and arguments" (Bohman and Richardson, 2009, 272), with the "point of civility" being "to engage the other as possessing practical intelligence, and so as capable of revising goals in the light of new understandings of one's circumstances and of reaching new understandings of one's circumstances in the light of newly accepted goals" (271).

\section{The Negative Functions of Calls for Civility}

\section{Silencing or Subjugating a Marginalized Group}

Just as incivility itself can be used to silence a minority view, condemnations of the "incivility" of those holding such views can function as a silencing mechanism or means of harassing a feared or subordinated group. The notion that calls for civility can be a means of social control (Strachan and Wolf, 2012, 47) is a long-lived one. In On Liberty, John Stuart Mill opined:

With regard to what is commonly meant by intemperate discussion, namely invective, sarcasm, personality, and the like, the denunciation of these weapons would deserve more sympathy if it were ever proposed to interdict them equally to both sides; but it is only desired to restrain the employment of them against the prevailing opinion: against the unprevailing they may not only be used without general (p. 212) disapproval, but will be likely to obtain for him who uses them the praise of honest zeal and righteous indignation. 
Yet whatever mischief arises from their use is greatest when they are employed against the comparatively defenceless. $(1910,150)$

Mill's observation is consistent with Lendler's claim that "inevitably, an appeal for enforced 'civility' becomes an argument for a specific side in a conflict" $(2004,424)$ and with concerns that condemnations of incivility can act "against a fully democratic order and in support of special interests, institutions of privilege, and structures of domination" (Kasson 1990, 3), by functioning "discursively to restrict content and participation though the limits they place on acceptable style" (Ferree et al., 2002, 313-314). For this reason, DeMott argues that the "'new incivility' needs to be recognized, in short, for what it is: a flat-out, justified rejection of the leader-class claims to respect, a demand that leader-class types start looking hard at themselves" $(1996,14)$. "The civility movement," argues Kennedy (1998) "is deeply at odds with what an invigorated liberalism requires: intellectual clarity; an insistence upon grappling with the substance of controversies; and a willingness to fight loudly, openly, militantly, even rudely for policies and values that will increase freedom, equality, and happiness in America and around the world."

\section{Unanswered Questions and Areas Requiring Future Research}

Synthesizing scholarly work on the effects of incivility is complicated by the fact that operationalizations of the term differ widely. In Mutz and Reeves's experiments $(2005,5)$ the "uncivil" conditions included statements such as "You're really missing the point here, Neil" and "What Bob is completely overlooking is"; "The candidates also raised their voices and never apologized for interrupting one another, nonverbal cues such as rolling of the eyes and rueful shaking of the head from side to side were also used to suggest lack of respect." By contrast, Brooks and Geer include explicit direct ad hominem attacks (e.g., "my unprincipled opponent," "my cowardly opponent," "my gutless opponent") on an opponent in the ads used in their experiments. Note, however, that consistent with our earlier point, the two projects do share the notion that incivility shows lack of respect for the views of another.

Those attempting to assess changes in civility across time within an institution or across media face other challenges. Reliably tracking behavior within the House of Representatives, for example, is complicated by the fact that before the 104th Congress changed the procedure, members were able to clean up their floor remarks before they were memorialized in the Congressional Record (Jamieson and Falk, 2000,105). Moreover, those trying to determine whether the level of civility on cable talk shows differs from one time to another must deal with the facts that the networks differ in the number of shows whose transcripts they release, some programs are repeated multiple (p. 213) times with slight alterations from airing to airing, and many programs are short lived. For example, four of the nine hosts whose shows Sobieraj and Berry $(2011,24-25)$ examined over a ten-week period in 2009 no longer have a home on the studied network. 
We close with the problem raised at the beginning of this chapter. The meaning attached to the concept of civility differs from one period to another and from one theorist to the next. One way to determine what the culture means by incivility at a given point in time is to ask what sorts of behaviors are awarded that label by dissimilar individuals commenting on the same body of discourse. Following that lead, Weitz, Volinsky, Jamieson (Jamieson 2012), and a team of coders at the Annenberg Public Policy Center found agreement among hosts on Fox, MSNBC, and CNN that the following classes of acts were uncivil:

- analogizing an opponent to Hitler or the Nazis

- extreme characterizations of opponents (e.g., as "barbarians" or a "mob")

- use of the language of violence (including Governor Perry's mock threat to get "ugly" with Fed chair Ben Bernanke if he were to go to Texas after pursuing loose monetary policy and Teamster leader Jimmy Hoffa's call to "take these sons of bitches out")

- extreme characterizations of legislation (including the notion that senior citizens would die under the opposing side's health plan)

- allegations that the president of an opposing party had lied (Rep. Wilson's "You lie" and statements by Democrats on the floor of the House alleging that President George W. Bush had done the same)

- dismissive or demeaning references to the president (i.e., calling President George W. Bush a "loser" and President Obama "kind of a dick")

- dismissive or demeaning references to others (e.g., labeling a female lobbyist a " $\mathrm{K}$ street whore" and a female senator a "hooker")

The study also explained why conservatives and progressive viewers enclaved within Fox or MSNBC programming might be disposed to consider incivility a problem plaguing only those on the other side of the aisle. Whereas Obama-Hitler analogies were more likely to be decried on MSNBC and CNN, Nazi analogies applied to Republican governor Walker were more often criticized on Fox. Whereas a FOX viewer was more likely to learn that Democrat Alan Grayson had labeled an advisor to Federal Reserve chairman Bernanke a "K Street whore," the viewer tuned to MSNBC was more likely to hear that conservative Glenn Beck had characterized Democratic senator Mary Landrieu as a hooker. The differences between FOX and MSNBC were significant and could be predicted by knowing the ideology of the transgressor.

\section{References}

Altschuler, G., and Blumin, S. 2000. Rude republic: Americans and their politics in the nineteenth century. Princeton, NJ: Princeton University Press.

Aminzade, R., and McAdam, D. 2002. Emotions and contentious politics. Mobilization: An International Quarterly, 7(2): 107-109. 
Anderson, A. A., Brossard, D., Scheufele, D. A., Xenos, M. A., and Ladwig, P. 2014. The "nasty effect": Online incivility and risk perceptions of emerging technologies. Journal of Computer-Mediated Communication, 19: 373-387.

Andersson, L., and Pearson, C. 1999. Tit for tat? The spiraling effect of incivility in the workplace. Academy of Management Review, 24(3): 452-471.

Arena, V. 2007. Roman oratorical invective. In W. Dominik and J. Hall (Eds.), A Companion to Roman Rhetoric (pp. 149-160). Oxford, UK: Blackwell Publishing.

Becker, M. 1988. Civility and society in Western Europe, 1300-1600. Bloomington: Indiana University Press.

Benson, T. 2011. The rhetoric of civility: Power, authenticity, and democracy. Journal of Contemporary Rhetoric, 1(1): 22-30.

Bohman, J., and Richardson, H. S. 2009. Liberalism, deliberative democracy, and 'reasons that all can accept'. The Journal of Political Philosophy, 17(3): 253-274.

Borah, P. 2013. Interactions of news frames and incivility in the political blogosphere: Examining perceptual outcomes. Political Communication, 30: 456-473.

Brooks, D., and Geer, J. 2007. Beyond negativity: The effects of incivility on the electorate. American Journal of Political Science, 51(1): 1-16.

Bryce, J. 1921. The American commonwealth. Vol. 1. New York: Macmillan.

Bryson, A. 1998. From courtesy to civility: Changing codes of conduct in early modern England. Oxford, UK: Oxford University Press.

Burger, W. 1975. The necessity for civility. Litigation, 1(1): 8-10, 62-63.

Carter, S. 1998. Civility: Manners, morals, and the etiquette of democracy. New York: Basic Books.

Chaucer, G. n.d. The Canterbury tales. Librarius Online Publication. Retrieved October 21, 2014, from http://www.librarius.com/canttran/mttrfs.htm.

Civility. n.d. In Wikipedia. Retrieved February 19, 2014, from http://en.wikipedia.org/ wiki/Wikipedia:Civility.

Coe, K., Kenski, K., and Rains, S. A. 2014. Online and uncivil? Patterns and determinants of incivility in newspaper website comments. Journal of Communication, 64: 658-679.

Cooper, T. 1792. A reply to Mr. Burke's invective against Mr. Cooper, and Mr. Watt: In the House of Commons on the 30th of April, 1792. Vol. 10, No. 6. London: J. Johnson, ... , and M. Falkner and Co. 
Craig, C. 2004. Audience expectations, invective, and proof. In J. Powell and J. Paterson (Eds.), Cicero the Advocate (pp. 187-214). Oxford, UK: Oxford University Press. doi: 10.1093/acprof:oso/9780198152804.003.0008

Darwall, S. 1977. Two kinds of respect. Ethics, 88(1): 36-49.

DeMott, B. 1996. Seduced by civility: Political manners and the crisis of democratic values. Nation, 263(19): 11-19.

Elias, N. 2000. The civilizing process: Sociogenetic and psychogenetic investigation. Oxford, UK: Blackwell.

Fehr, E., and Fischbacher, U. 2004. Social norms and human cooperation. Trends in Cognitive Sciences, 8(4): 185-190.

(p. 215) Ferree, M., Gamson, W., Gerhards, J., and Rucht, D. 2002. Four models of the public sphere in modern democracies. Theory and Society, 31(3): 289-324.

Furey, C. 2005. Invective and discernment in Martin Luther, D. Erasmus, and Thomas More. Harvard Theological Review, 98(4): 469-488.

Gawronski, B., Bodenhausen, G., and Banse, R. 2005. We are, therefore they aren't: Ingroup construal as a standard of comparison for outgroup judgments. Journal of Experimental Social Psychology, 41(5): 515-526.

Gervais, B. T. 2015. Incivility online: Affective and behavioral reactions to uncivil political posts in a web-based experiment. Journal of Information Technology \& Politics, 12(2): 167-185.

Gillingham, J. 2002. From civilitas to civility: Codes of manners in medieval and early modern England. Transactions of the Royal Historical Society (Sixth Series), 12: 267-289.

Gould, D. 2009. Moving politics: Emotion and ACT UP's fight against AIDS. Chicago: University of Chicago Press.

Gutmann, A., and Thompson, D. 1996. Democracy and disagreement. Cambridge, MA: Harvard University Press.

Hayek, F. 1976. Law, legislation and liberty. Vol. 2, The mirage of social justice. Chicago: University of Chicago Press.

Herbst, S. 2010. Rude democracy: Civility and incivility in American politics. Philadelphia: Temple University Press.

Jamieson, K. H. 2000. Incivility and its discontents: Lessons learned from studying civility in the US House of Representatives. Boston: Allyn and Bacon. 
Jamieson, K. H. 2012. Cable news networks increase amount and public accessibility of incivility. March 27. Retrieved from http://www.flackcheck.org/press/press-release-incivility-in-public-discourse/.

Jamieson, K. H., and Cappella, J. 2008. Echo chamber: Rush Limbaugh and the conservative media establishment. New York: Oxford University Press.

Jamieson, K. H., and Dunn, J. 2008. The "B" word in traditional news and on the web. Nieman Reports (Summer). Retrieved from http://www.nieman.harvard.edu/reports/article/100020/The-B-Word-in-Traditional-News-and-on-the-Web.aspx.

Jamieson, K. H., and Falk, E. 2000. Continuity and change in civility in the House. In J. Bond and R. Fleisher (Eds.), Polarized Politics: Congress and the President in a Partisan Era (pp. 96-108). Washington, DC: Congressional Quarterly Press.

Jefferson, T. 1868. A manual of parliamentary practice: For the use of the Senate of the United States. New York: Clark \& Maynard Publishers.

Kasson, J. F. 1990. Rudeness and civility: Manners in nineteenth-century urban America. New York: Hill and Wang.

Kennedy, R. 1998. The case against civility. American Prospect, 9(41): 84-89.

Knox, D. 1995. Erasmus' "De Civilitate” and the religious origins of civility in Protestant Europe. Archiv für Reformationsgeschichte, 86: 7-55.

Koster, S. 1980. Die invektive in der griechischen und römischen Literatur. Meisienheim am Glan, DE: A. Hain.

Lendler, M. 2004. Equally proper at all times and at all times necessary: Civility, bad tendency, and the sedition act. Journal of the Early Republic, 24(3): 419-444.

Leyens, J., Cortes, B., Demoulin, S., Dovidio, J., Fiske, S., Gaunt, R., Paladino, M., Rodriguez-Perez, A., Rodriguez-Torres, R., and Vaes, J. 2003. Emotional prejudice, essentialism, and nationalism: The 2002 Tajfel lecture. European Journal of Social Psychology, 33(6): 703-717.

Linville, P., and Fischer, G. 1993. Exemplar and abstraction models of perceived group variability and stereotypicality. Social Cognition, 11(1): 92-125.

(p. 216) Lynch, M. 2011. Reasons for reason. New York Times, October 2. Retrieved from http://opinionator.blogs.nytimes.com/2011/10/02/reasons-for-reason/? _php=true\&_type=blogs\&_r=0.

Mill, J. 1910. Utilitarianism, liberty, \& representative government. New York: E. P. Dutton.

Murray, Stephen O. 1983. Ritual and personal insults in stigmatized subcultures. GayBlack-Jew. Maledicta, 7: 189-211. 
Mutz, D. 2007. Effects of "in your face" television discourse on perceptions of a legitimate opposition. American Political Science Review, 101(4): 621-635.

Mutz, D., and Reeves, B. 2005. The new videomalaise: Effects of televised incivility on political trust. American Political Science Review, 99(1): 1-15.

Nickels, I. 1995. Decorum in the House. Washington, DC: Congressional Research Service.

Ost, D. 2004. Politics as the mobilization of anger. European Journal of Social Theory, 7(2): $229-244$.

Papacharissi, Z. 2004. Democracy online: Civility, politeness, and the democratic potential of online political discussion groups. New Media and Society, 6(2): 259-283.

Phillips, T., and Smith, P. 2003. Everyday incivility: Towards a benchmark. Sociological Review, 51(1): 85-108.

Porath, C., and Erez, A. 2007. Does rudeness really matter? The effects of rudeness on task performance and helpfulness. Academy of Management Journal, 50(5): 1181-1197.

Porath, C., and Erez, A. 2009. Overlooked but not untouched: How rudeness reduces onlookers' performance on routine and creative tasks. Organizational Behavior and Human Decision Processes, 109(1): 29-44.

Rafaeli, A., Erez, A., Ravid, S., Derfler-Rozin, R., Treister, D., and Scheyer, R. 2012. When customers exhibit verbal aggression, employees pay cognitive costs. Journal of Applied Psychology, 97(5): 931-950.

Rawls, J. 1996. Political liberalism: The John Dewey essays in philosophy. New York: Columbia University Press.

Reno, R., Cialdini, R., and Kallgren, C. 1993. The transsituational influence of social norms. Journal of Personality and Social Psychology, 64(1): 104-112.

Robbins, J., and Krueger, J. 2005. Social projection to ingroups and outgroups: A review and meta-analysis. Personality and Social Psychology Review, 9(1): 32-47.

Santana, A. D. (2014). Virtuous or vitriolic: The effect of anonymity on civility in online newspaper reader comment boards. Journalism Practice, 8(1): 18-33.

Schudson, M. 1997. Why conversation is not the soul of democracy. Critical Studies in Media Communication, 14(4): 297-309.

Shils, E. 1997. Civility and civil society: Good manners between persons and concern for the common good in public affairs. In S. Grosby (Ed.), The Virtue of Civility: Selected Essays on Liberalism, Tradition and Civil Society (pp. 63-102). Indianapolis, IN: Liberty Fund. 
Simpson, D. 1960. Cassell's New Latin dictionary. Latin-English, English-Latin. New York: Funk and Wagnalls.

Sinopoli, R. 1995. Thick-skinned liberalism: Redefining civility. American Political Science Review, 89(3): 612-620.

Sobieraj, S., and Berry, J. 2011. From incivility to outrage: Political discourse in blogs, talk radio, and cable news. Political Communication, 28(1): 19-41.

Strachan, J., and Wolf, M. 2012. Calls for civility: An invitation to deliberate or a means of political control? In D. M. Shea and M. P. Fiorina (Eds.), Can We Talk? The Rise of Rude, Nasty, Stubborn Politics (pp. 41-52). New York: Pearson.

Stroud, N. J., Scacco, J. M., Muddiman, A., and Curry, A. L. 2015. Changing deliberative norms on news organizations' Facebook sites. Journal of Computer-Mediated Communication, 20(2): 188-203.

Thorson, K., Vraga, E., and Ekdale, B. 2010. Credibility in context: How uncivil online commentary affects news credibility. Mass Communication and Society, 13: 289-313.

(p. 217) Uslaner, E. 1996. The decline of comity in Congress. Ann Arbor: University of Michigan Press.

Vasquez, E., Pedersen, W., Bushman, B., Kelley, N., Demeestere, P., and Miller, N. 2013. Lashing out after stewing over public insults: The effects of public provocation, provocation intensity, and rumination on triggered displaced aggression. Aggressive Behavior, 39(1): 13-29.

Vrooman, S. 2002. The art of invective performing identity in cyberspace. New Media \& Society, 4(1): 51-70. (p. 218)

\section{Notes:}

(1.) For the definitive treatment of invective in ancient Rome, see Koster (1980). For a sophisticated treatment of Cicero's use of invective, see Craig (2004, 187-213).

\section{Kathleen Hall Jamieson}

Kathleen Hall Jamieson, Elizabeth Ware Packard Professor of Communication, Annenberg School of Communication, University of Pennsylvania

\section{Allyson Volinsky}

Allyson Volinsky is a doctoral student in the Annenberg School for Communication at the University of Pennsylvania.

\section{Ilana Weitz}


Ilana Weitz is a research coordinator at the Annenberg Public Policy Center and M.P. A. candidate in the Fels Institute of Government at the University of Pennsylvania.

\section{Kate Kenski}

Kate Kenski (Ph.D., University of Pennsylvania) is an Associate Professor of Communication at the University of Arizona where she teaches political communication, public opinion, and research methods. Her book The Obama Victory: How Media, Money, and Message Shaped the 2008 Election (co-authored with Bruce W. Hardy and Kathleen Hall Jamieson; 2010, Oxford University Press) has won several awards including the 2011 ICA Outstanding Book Award and the 2012 NCA Diamond Anniversary Book Award. Her current research focuses on incivility in online forums and multimedia teaching strategies to mitigate cognitive biases. 